\title{
Folate-responsive homocystinuria and megaloblastic anaemia in a female patient with functional methionine synthase deficiency (cblE disease)
}

\author{
B. FOWLER ${ }^{1}$, R.B.H. SCHUTGENS ${ }^{2}$, D.S. RosenblatT ${ }^{3}$, G.P.A. SMIT ${ }^{4}$, \\ J. LINDEMANS ${ }^{5}$ \\ ${ }^{1}$ Basel University Children's Hospital, Basel, Switzerland; ${ }^{2}$ Department of Pediatrics, \\ University of Amsterdam, Amsterdam, The Netherlands; ${ }^{3}$ Division of Medical Genetics, \\ Department of Medicine, McGill University, Montreal, Quebec, Canada; ${ }^{4}$ Department of \\ Pediatrics, University Hospital of Groningen, Groningen, The Netherlands; ${ }^{5}$ Department \\ of Clinical Chemistry, Erasmus University Rotterdam, Rotterdam, The Netherlands. \\ *Correspondence: Basel University Children's Hospital, Postfach 4005, Basel, \\ Switzerland
}

MS received 6.6.96 Accepted 24.2.97

\begin{abstract}
Summary: This first detailed report of a female patient with functional methionine synthase deficiency due to the cblE defect describes treatment with several vitamins and cofactors and clinical progress for 17 years. Before treatment, major findings were microcephaly, psychomotor retardation, episodic reduced consciousness, megaloblastic anaemia, increased plasma free homocystine $(>20 \mu \mathrm{mol} / \mathrm{L})$, low plasma methionine $(<10 \mu \mathrm{mol} / \mathrm{L})$ and increased excretion of formiminoglutamate. On high-dose folic acid, biochemical abnormalities such as formiminoglutamate excretion and homocystinuria nearly normalized, but clinical and haematological abnormalities remained. On replacement of folate with methylcobalamin, alertness, motor function, speech and the electroencephalogram improved, biochemical features were similar, but the mean corpuscular volume increased. The best control was observed on a combination of folate and methylcobalamin. At 17 years of age she remains severely mentally retarded.

In cultured fibroblasts methionine synthesis was reduced $(0.03 \mathrm{nmol} / \mathrm{mg} / \mathrm{per} 16 \mathrm{~h}$, controls 2.4-6.9); methionine synthase activity was normal under high reducing conditions but decreased on limiting the reducing agent, dithiothreitol, to $5 \mathrm{mmol} / \mathrm{L}$ (18\% of total, controls 51-81\%); formation of methylcobalamin was low $(4.5 \%$ of total cobalamins, control $57.5 \%$ ) and complementation studies indicated the cblE defect. Methionine formation showed only minor increases in cells grown in folateor cobalamin-supplemented medium. Serine synthesis, which was low in normal medium, increased with cobalamin supplementation. These studies suggest further heterogeneity within cblE mutants, show the difficulty of establishing the enzyme defect in vitro, and indicate a role for folate in addition to cobalamin in treatment.
\end{abstract}




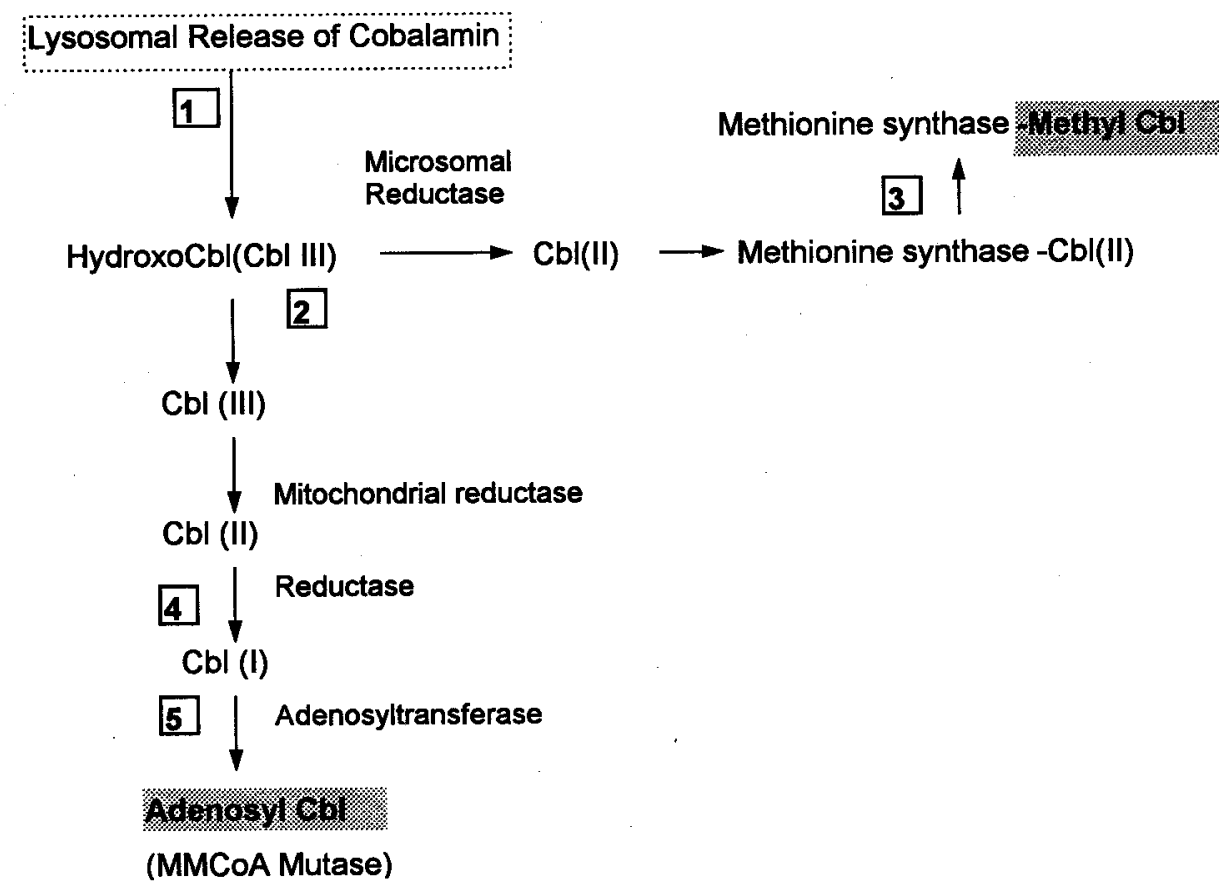

Figure 1 Intracellular processing of cobalamins. The main steps in the pathway are summarized. The numbers indicate the sites of genetic defects as follows: (1) cblF; (2) cblC/D (exact site not known); (3) cblE/G; (4) cblA; (5) cblB

In man there are two known reactions which require vitamin $\mathrm{B}_{12}$ (cobalamin; cbl) cofactors for activity. One is adenosylcobalamin (Adocbl)-dependent methylmalonyl-CoA mutase (EC 5.4.99.2), which catalyses the conversion of methylmalonyl-CoA to succinyl-CoA. The other is methylcobalamin (Mecbl)-dependent 5-methyltetrahydrofolate:homocysteine methyltransferase (methionine synthase, EC 2.1.1.13), which converts homocysteine to methionine (Fenton and Rosenberg 1995). These coenzymes are formed from their vitamin precursor hydroxocobalamin by a complex sequence of processes (Figure 1). Adocbl is formed from hydroxocobalamin intramitochondrially by successive reductions of the cobalt atom followed by adenosyl group transfer. Defects of Adocbl formation, cblA (McKusick 251100) and cblB (McKusick 251110), result in methylmalonic aciduria. Mecbl is formed from hydroxocobalamin in the cytoplasm by the catalytic action of methionine synthase. This enzyme is crucial for proper recycling of folate and its coenzymes and thereby provides an important link between cobalamin and folate metabolism. Defects of steps in cobalamin processing which are common to both coenzymes result in combined homocystinuria and methylmalonic aciduria, designated on the basis of genetic complementation analysis as cblC (McKusick 277400), cblD (McKusick 277410) and cblF (McKusick 277380). Homocystinuria associated with altered methionine synthase activity and deficient Mecbl synthesis but normal Adocbl formation has been found in patients with either the cblE (McKusick 236270) or cblG (McKusick 250940) defect. In the 12 patients 
reviewed in detail (Watkins and Rosenblatt 1989; Hall 1990) anaemia, megaloblastosis, mental retardation and neurological abnormalities were common findings. All patients have shown varying degrees of biochemical and clinical response to treatment with cobalamin. The effect of folate or folinic acid on the biochemical and clinical outcome is unclear since they have been used mainly in combined treatments. However, in one cblE patient no effect was reported (Schuh et al 1984) while in a cblG patient some benefit was seen (Shin et al 1986). So far 5 males with the cblE defect have been described (Schuh et al 1984; Rosenblatt et al 1985; Tuchman et al 1988) but two females are known anecdotally (Fenton and Rosenberg 1995). Much clinical and biochemical heterogeneity is evident among cblE and cblG patients. In this paper we describe a female patient with deficient methionine synthesis in cultured fibroblasts due to the cblE defect who shows clinical and biochemical differences from previously reported cblE patients. The response of amino acid levels and haematological abnormalities to treatment with various cofactors in vivo compared with responsiveness of methionine synthesis and serine formation in cultured fibroblasts and the long-term clinical outcome are reported.

\section{MATERIALS AND METHODS}

Vitamin $B_{12}$ (Gijzen et al 1983) and vitamin $B_{6}$ (Anderson et al 1970) were measured microbiologically and folate was determined as described by Voogd (Voogd et al 1985). Formiminoglutamic acid was determined (Tabor and Wijngarden 1958) and L-histidine loading was performed (Niederwieser et al 1974) as described. Blood concentrations of cobalamins were measured as reported (van Kapel et al 1983). Plasma and urine amino acids including free homocystine were measured after deproteinization (sulphosalicylic acid) using a Beckman 121M amino acid analyser. Urinary organic acids were analysed gas-chromatographically as trimethylsilyl derivatives essentially as previously described (Duran et al 1978). Skin fibroblasts were grown in Eagle's minimum essential medium containing undialysed fetal calf serum $(10 \% \mathrm{v} / \mathrm{v})$, nonessential amino acids $(1 \% \mathrm{w} / \mathrm{v})$ and kanamycin $(100 \mathrm{mg} / \mathrm{L})$. Cell cultures were periodically tested to exclude mycoplasma contamination. Confluent cultures were harvested using trypsin $(0.25 \% \mathrm{w} / \mathrm{v})$ then stored at $-70^{\circ} \mathrm{C}$ prior to assays.

Dihydrofolate reductase (Mukulu et al 1973) and glutamate formiminotransferase (Niederwieser et al 1974) were measured in liver (needle biopsy) as reported. Methylenetetrahydrofolate reductase activity was assayed both in liver and in cultured fibroblasts as described (Rosenblatt and Erbe 1977). Cystathionine $\beta$-synthase was assayed in cultured fibroblasts as previously described (Fowler et al 1978). Methionine synthase was assayed in cultured fibroblasts as described by Mellman (Mellman et al 1978). All enzyme activities were related to protein determined by the Lowry method (Lowry et al 1951).

Incorporation of label from $\left[{ }^{14} \mathrm{C}\right]$ propionate into protein was assayed in intact fibroblast monolayer cultures (Willard et al 1976). Methionine formation from homocysteine was determined in fibroblast monolayer cultures as previously described (Fowler 1982) except that in some experiments $\left[{ }^{14} \mathrm{C}\right]$ formate was used as the labelled precursor in place of $\left[{ }^{35}\right.$ S ]homocysteine (Boss 1985). In these experiments cells were incubated with $5 \mathrm{ml}$ of Earle's basic salt solution which contained $\left[{ }^{14} \mathrm{C}\right]$ formate $(2 \mu \mathrm{Ci} / \mathrm{ml})$, sodium formate $(250 \mu \mathrm{mol} / \mathrm{L})$ and $\mathrm{L}$-homocysteine $(200 \mu \mathrm{mol} / \mathrm{L})$ prepared freshly from its thiolactone 
(Fowler et al 1978). This modification allowed simultaneous measurement of methionine and serine formation. In some experiments cells were grown in normal medium for 4 days followed by growth for 3 days in medium supplemented with various cofactors.

Complementation studies were performed as previously described (Watkins and Rosenblatt 1988). Synthesis of cobalamin coenzymes from $\left[{ }^{57} \mathrm{Co}\right]$ cyanocobalamin was measured in cultured fibroblasts as previously described (Rosenblatt et al 1984).

All radiochemicals were obtained from Amersham International. Tissue culture materials were purchased from Gibco Europe and all other chemicals were of the highest purity commercially available.

Patient history: The patient was the first child born to healthy parents after a normal pregnancy and delivery. There were no earlier pregnancies. The birth weight was $3090 \mathrm{~g}$, length was $51 \mathrm{~cm}$ and head circumference was normal. A sibling born later has developed normally. The patient first presented at 6 months of age with feeding problems, with weight falling from the 25th centile at 6 weeks to below the 10th centile at 6 months. Bilateral clinodactyly and bilateral syndactyly were present. There was microcephaly (head circumference below the 5th centile), but no neurodevelopmental abnormalities were observed. Marked anaemia (haemoglobin $(\mathrm{Hb}) 5.1 \mathrm{mmol} / \mathrm{L}$, haematocrit $(\mathrm{Ht}) 0.24$, mean corpuscular volume (MCV) $122 \mathrm{fl}$ ) was found which was unresponsive to iron treatment and was shown to be megaloblastic by bone marrow and blood smear examination.

At the age of 14 months the patient had a limited ability to walk and speak, but this was progressively lost starting at about 16 months of age. At this age, periods of lowered consciousness with staring and long sleeping periods during the day were observed. At 21 months of age she was unable to sit or stand, her upper limbs were hypotonic and her legs were hypertonic, indicating that regression had occurred. During the second year of life the head circumference decreased to below the 3 rd centile, weight remained below the 10th centile and height at the 25 th centile. When she was seen at 22 months, anaemia was still evident ( $\mathrm{Hb} 5.5 \mathrm{mmol} / \mathrm{L}$, Ht 0.28 , MCV $132 \mathrm{fl}$ ). The electroencephalogram showed underdeveloped differentiation and diffuse irregularities but no epileptic abnormalities, and a computer tomography scan revealed a limited diffuse widening of the ventricular system.

At 2 years of age, screening for metabolic disorders revealed excessive excretion of homocystine, sulphite and formiminoglutamic acid. In plasma, free homocystine concentration was increased $(20 \mu \mathrm{mol} / \mathrm{L}$, normal not detectable) with low methionine concentration $(10 \mu \mathrm{mol} / \mathrm{L}$, normal $28-40)$. In addition, formiminoglutamic acid excretion was elevated on several occasions, ranging from 30 to $190 \mu \mathrm{mol} / \mathrm{mmol}$ creatinine (normal $0-15)$. Plasma concentrations of vitamin $\mathrm{B}_{12}(446 \mathrm{pmol} / \mathrm{L})$, folate $(34 \mathrm{nmol} / \mathrm{L})$ and vitamin $\mathrm{B}_{6}(59 \mathrm{nmol} / \mathrm{L})$ were normal. Folate concentration $(50 \mathrm{nmol} / \mathrm{L})$ was also normal in cerebrospinal fluid. Urinary organic acids were normal with no increase of methylmalonic acid. The Schilling test showed normal vitamin $B_{12}$ absorption. Normal concentration of transcobalamins I, II and III and unsaturated $\mathrm{B}_{12}$ binding capacity were found, providing further evidence of normal vitamin $\mathrm{B}_{12}$ uptake (assays performed by $\mathrm{Dr}$ V. Herbert, Haematology and Nutrition Laboratory, Veterans Administration Hospital, Bronx, New York, USA). The previously observed haematological abnormalities persisted, with severely megaloblastic bone marrow containing a high number of cells, hypersegmentation 
Table 1 Main treatment modalities in the patient

\begin{tabular}{llr}
\hline Age (years) & Specific treatment & $M C V(\mathrm{fl})$ \\
\hline $0-2$ & None & $122-132$ \\
$2-7$ & Folate $(40 \mathrm{mg} / \mathrm{day}$, oral) & $108-114$ \\
$7-8$ & Folate $(40 \mathrm{mg} /$ day, oral $)+$ methylcobalamin $(1 \mathrm{mg}$ i.m., monthly) & $104-110$ \\
$8-13$ & Methylcobalamin (1mg i.m., monthly) & $115-118$ \\
$13-17$ & Methylcobalamin (1mg i.m., monthly) + folate (40mg/day, oral) & $100-109$ \\
\hline
\end{tabular}

and abnormal cell divisions (megaloblastic cells 20\%; normoblasts $4.5 \%$; polychromatic erythroblasts $6.25 \%$ ).

During the following years various treatments were tried in attempts to correct the haematological, biochemical and clinical abnormalities (see Table 1 and below). Treatment with folate $(40 \mathrm{mg} / \mathrm{day}$, oral) from 2 to 7 years of age resulted in the following changes compared with the immediate pretreatment values. Plasma methionine increased from 10 to $26 \mu \mathrm{mol} / \mathrm{L}$; plasma and urine homocystine fell from $10 \mu \mathrm{mol} / \mathrm{L}$ to undetectable and from 40 to $10 \mu \mathrm{mol} / 24 \mathrm{~h}$, respectively; $\mathrm{Hb}$ increased from 5.1 to $7.8 \mathrm{mmol} / \mathrm{L}$ and the $\mathrm{MCV}$ fell from 132 to $110 \mathrm{fl}$. Formiminoglutamic acid excretion after histidine loading was much lower at 980 and $260 \mu \mathrm{mol} / 24 \mathrm{~h}$ (normal $0-12$ ) compared with $2980 \mu \mathrm{mol} / 24 \mathrm{~h}$ before treatment.

At the age of 3 years, hydroxocobalamin ( $1 \mathrm{mg}$ i.m. 2 weekly) was added for a period of only 2 months. This was discontinued since no additional positive effect on the MCV was found.

In spite of the biochemical and haematological response to folate, poor growth continued and mental retardation, hyperreflexia and spasticity remained. During this period several episodes of reduced consciousness necessitated admissions to hospital. At 6.5 years of age, the electroencephalogram showed a generalized form of epilepsy which was treated with valproic acid. Also, bone marrow examinations repeatedly showed megaloblastic characteristics. At 7 years of age the computed tomography scan again showed slightly enlarged ventricles. At this time the serum concentration of Mecbl was found to be low ( $21 \mathrm{pmol} / \mathrm{L}=4 \%$ of total; controls $(n=15) 182 \pm 50 \mathrm{pmol} / \mathrm{L}=46.9 \%)$.

From the age of 7 years 2 months she was treated for 1 year with Mecbl (Algobaz, $1.0 \mathrm{mg}$ i.m. monthly) combined with folate $(40 \mathrm{mg}$ /day) resulting in good control of plasma and urine homocystine concentrations and reduced megaloblastic changes (MCV 104-110). After 6 months on this treatment there was a clear clinical improvement indicated by better consciousness and reduced daytime sleeping, and some improvement of motor function and speech.

From 8 years 2 months to 13 years of age, treatment was with Mecbl alone, with MCV values of 115-118. At 12.5 years of age, weight and length were at the 25 th centile but microcephaly remained with the head circumference below the 3 rd centile. At 13 years of age, some clinical deterioration was observed with lowered consciousness, and daytime sleeping was observed together with further loss of motor function and speech. Folate treatment (40mg/day) was then reintroduced in combination with Mecbl (1.0mg i.m. monthly, see Table 1) with a fall in the MCV value; while plasma and urine homocystine remained undetectable, plasma methionine was $20 \mu \mathrm{mol} / \mathrm{L}$, and $\mathrm{Hb} 7.45-7.95 \mathrm{mmol} / \mathrm{L}$. Shortly afterwards she became more alert during the day, suggesting an additional effect of folate. 
At 17 years of age, no further change in her clinical state was observed. Psychological assessment in this microcephalic juvenile showed function at the 3.5-year level.

\section{RESULTS}

Enzyme studies: Several enzymes were assayed in either a needle liver biopsy or cultured skin fibroblasts (Table 2). The activities of dihydrofolate reductase (liver), methylenetetrahydrofolate reductase (liver and cultured fibroblasts), glutamate formiminotransferase (liver) and cystathionine $\beta$-synthase (cultured fibroblasts) were all within the control ranges.

Studies in intact fibroblasts Incorporation of label from $\left[{ }^{14} \mathrm{C}\right]$ propionate into trichloroacetic acid-precipitable protein was normal $(9.8 \mathrm{nmol} / \mathrm{mg}$ per $16 \mathrm{~h}$ : controls $(n=29) 4.2-19.6)$. In contrast, labelled methionine formation from homocysteine in cells grown in unsupplemented medium was markedly deficient using both $\left[{ }^{35} \mathrm{~S}\right]$ homocysteine $(0.09-0.21 \mathrm{nmol} / \mathrm{mg}$ per $16 \mathrm{~h}$, mean 0.15; controls $(n=24) 4.5-14.1$, mean 7.4$)$ and $\left[{ }^{14} \mathrm{C}\right]$ formate $(0.01-0.05 \mathrm{nmol} / \mathrm{mg}$ per $16 \mathrm{~h}$, mean 0.03; controls $(n=19)$ 2.4-6.9, mean 3.6) as the labelled precursor. Clearly reduced formation of labelled serine from $\left[{ }^{14} \mathrm{C}\right]$ formate label was also found $(0.54-1.85 \mathrm{nmol} / \mathrm{mg}$ per 16h, mean 0.86; controls $(n=16)$ 2.8-10.3, mean 5.5). There was no appreciable increase of labelled methionine or serine formation in patient cells grown in media supplemented with the following: (1) folate (up to $200 \mathrm{mg} / \mathrm{L}$ ); (2) folinic acid ( $40 \mathrm{mg} / \mathrm{L})$; (3) methyltetrahydrofolate (up to $200 \mathrm{mg} / \mathrm{L}$ ); (4) folate and methylcobalamin in combination $(200 \mathrm{mg} / \mathrm{L}$ and $1 \mathrm{mg} / \mathrm{L}$, respectively); (5) methyltetrahydrofolate and methylcobalamin in combination $(200 \mathrm{mg} / \mathrm{L}$ and $1 \mathrm{mg} / \mathrm{L}$, respectively).

Labelled serine formation increased from 0.86 in normal medium to 1.05 and $1.2 \mathrm{nmol} / \mathrm{mg}$ per $16 \mathrm{~h}$ in medium supplemented with 1 or $10 \mathrm{mg} / \mathrm{L}$ of hydroxocobalamin, respectively ( $19 \%$ and $21 \%$ of the mean control value), while the formation of methionine increased from 0.03 to 0.08 and $0.09 \mathrm{nmol} / \mathrm{mg}$ per $16 \mathrm{~h}$, respectively. However, these increased methionine values represent only $2-2.5 \%$ of the mean control value. Corresponding values for medium supplemented with the same concentrations of methylcobalamin were $0.024(1 \mathrm{mg} / \mathrm{L})$ and $0.06 \mathrm{nmol} / \mathrm{mg}$ per $16 \mathrm{~h}(10 \mathrm{mg} / \mathrm{L})$ for methionine formation, and 0.72 and $0.95 \mathrm{nmol} / \mathrm{mg}$ per $16 \mathrm{~h}$ for serine synthesis.

Table 2 Enzymes of folate and homocysteine metabolism: activities in liver and skin fibroblasts

\begin{tabular}{lccc}
\hline Enzyme & Tissue & Patient & Controls \\
\hline $\begin{array}{l}\text { Dihydrofolate reductase } \\
\text { (nmol/min per mg protein) }\end{array}$ & Liver & $4.6,4.3$ & $3.8-5.4(n=3)$ \\
$\begin{array}{l}\text { Glutamate formiminotransferase } \\
\text { (nmol/min per mg protein) }\end{array}$ & Liver & 1350 & 854 \\
$\begin{array}{l}\text { Methylene THF reductase } \\
\text { (nmol/h per mg protein) }\end{array}$ & Liver & $5.5,5.2$ & $4.4-6.4(n=4)$ \\
$\begin{array}{l}\text { Methylene THF reductase } \\
\text { (nmol/h per mg protein) }\end{array}$ & Fibroblasts & 5.1 & $3.7-16(n=32)$ \\
$\begin{array}{l}\text { Cystathionine } \beta \text {-synthase } \\
\text { (nmol/h per mg protein) }\end{array}$ & Fibroblasts-PLP & 8.1 & $3.6-25.7(n=29)$ \\
\hline
\end{tabular}

${ }^{\mathrm{a}} \mathrm{THF}$, tetrahydrofolate

${ }^{\mathrm{b}}$ PLP, pyridoxal 5'-phosphate 
Finally it should be noted that no decrease of serine formation was observed in control or patient cells supplemented with methyletetrahydrofolate compared with unsupplemented medium.

Methionine synthase (MS) activity in cultured fibroblasts: When MS was assayed with strong reducing conditions $(150 \mathrm{mmol} / \mathrm{L} \beta$-mercaptoethanol), activity in patient fibroblasts was within or a little below the control range (Table 3 ). The different values reflect the known variability of this assay. Holoenzyme activity measured in the absence of added coenzyme, methylcobalamin, was not reduced. Importantly, in two experiments activity in the presence of $5 \mathrm{mmol} / \mathrm{L}$ dithiothreitol as the added thiol, expressed as a percentage of the activity with $\beta$-mercaptoethanol, was significantly lower in the patient cell extracts than in controls $(18 \%$ and $19 \%$ of the activity with $\beta$-mercaptoethanol compared with $83 \%, 51 \%$, $80 \%$ and $69 \%$ in controls).

Complementation studies: The uptake of radioactivity from $\left[{ }^{14} \mathrm{C}\right]$ methyltetrahydrofolate into protein was measured in the patient fibroblasts fused with cells known to belong to either the cblE or cblG mutation class. In the patient cells mixed with cblE cells uptake was 55 and $52 \mathrm{pmol} / 18 \mathrm{~h}$ per $\mathrm{mg}$ protein in the absence (unfused) and in the presence (fused) of polyethylene glycol, respectively. In contrast, in cells mixed wtih two cblG cell lines, uptake of label was $56 \mathrm{pmol} / 18 \mathrm{~h}$ per $\mathrm{mg}$ protein unfused versus 108 fused, and 50 unfused versus 80 fused. These are $93 \%$ and $50 \%$ increases, indicating complementation with the cblG cells but not with the cblE cells.

Cobalamin coenzymes in blood and cultured fibroblasts: The proportion of the methyl form in blood was clearly reduced, with normal amounts of adenosylcobalamin without treatment (see above). The synthesis of cobalamin coenzymes measured in cultured fibroblasts is shown in Table 4. The formation of methylcobalamin was much lower in the patient cells than in a simultaneously studied control cell line, although the total cobalamin uptake was similar.

Table 3 Methionine synthase activity in fibroblasts ( $\mathrm{pmol} / \mathrm{min}$ per $\mathbf{m g}$ protein) ${ }^{\mathrm{a}}$

\begin{tabular}{lccccc}
\hline Conditions & $\begin{array}{c}\text { Complete } \\
\text { 150mmol/L BME } \\
+ \text { Mecbl }^{\mathrm{b}}\end{array}$ & $\begin{array}{c}\text { Complete } \\
\text { 150mmol/L BME } \\
- \text { Mecbl }\end{array}$ & $\begin{array}{c}\text { No added } \\
\text { thiol } \\
+ \text { Mecbl }\end{array}$ & $\begin{array}{c}5 \text { mmol/L DTT } \\
+ \text { Mecbl }\end{array}$ & $\begin{array}{c}\text { 25mmol/L DTT } \\
+ \text { Mecbl }\end{array}$ \\
\hline Control 1 & 110 & $41(37)$ & $3(3)$ & $91(83)$ & $102(92)$ \\
Control 2 & 95 & & & $49(51)$ & \\
Control 3 & 105 & & $84(80)$ & \\
Control 4 & 112 & & & $77(69)$ & \\
Control range & $58-150$ & $58(55)$ & $2(2)$ & $20(19)$ & $72(68)$ \\
Patient & $105(100)$ & & & $9(18)$ & \\
Patient repeat & $51(100)$ & & & & \\
\hline
\end{tabular}

a The values in parentheses are the percentage of the activity in the complete assay with added Mecbl

${ }^{\mathrm{b}}$ BME, $\beta$-mercaptoethanol

${ }^{\mathrm{c}} \mathrm{Mecbl}$, methylcobalamin $50 \mu \mathrm{mol} / \mathrm{L}$

${ }^{\mathrm{d}}$ DTT, dithiothreitol

e Range of activity in the complete assay obtained with controls 1-4 plus 6 additional control cell lines 
Table 4 Formation of cobalamins in cultured fibroblasts

\begin{tabular}{|c|c|c|c|c|c|c|c|}
\hline & \multicolumn{2}{|c|}{ Cobalamin uptake (per $10^{6}$ cells) } & \multicolumn{4}{|c|}{ Cobalamin distribution (\% of total) } & \multirow[b]{2}{*}{ Other } \\
\hline & $(\mathrm{cpm})$ & $(\mathrm{pg})$ & $A q^{\mathrm{a}}$ & $C N^{\mathrm{b}}$ & Adenosyl & Methyl & \\
\hline \multirow[t]{2}{*}{ Control } & 2443 & 7 & 2.5 & 12 & 19 & 57.5 & 9 \\
\hline & 2422 & 7 & & & & & \\
\hline \multirow[t]{2}{*}{ Patient } & 4397 & 11.7 & 9 & 28 & 29.5 & 4.5 & 29 \\
\hline & 4271 & 11.4 & & & & & \\
\hline
\end{tabular}

${ }^{a} \mathrm{Aq}$, aquacobalamin,

${ }^{\mathrm{b}} \mathrm{CN}$, cyanocobalamin

\section{DISCUSSION}

There is conclusive evidence for a disorder of methionine synthase function in this patient. First, increased blood and urine concentrations of homocystine with low blood levels of methionine were present together with normal methylenetetrahydrofolate reductase activity in liver and fibroblasts. Second, synthesis of methionine from either labelled homocysteine or labelled formate in fibroblasts was reduced, indicating defective remethylation of homocysteine. There was no methylmalonic aciduria in this child, together with normal uptake of labelled propionate into protein in fibroblasts, indicating normal methylmalonylCoA mutase-dependent conversion of propionate to succinate. This rules out a combined defect due to abnormal cytosolic or lysosomal cobalamin processing (cblC, cblD or cblF defect). Third, methionine synthase activity was deficient in cultured fibroblasts when assayed under low reducing conditions, as reported for other patients with the cblE defect (Rosenblatt et al 1984). Fourth, methylcobalamin levels were reduced in blood and in cultured fibroblasts. Finally, complementation studies confirmed the cblE defect.

Several features in this patient can be explained by the methyl trap hypothesis as proposed in a patient with combined homocystinuria and methylmalonic aciduria (Baumgartner et al 1985) and also implicated in vitamin $\mathrm{B}_{12}$ deficiency (Higginbottom et al 1978). In this hypothesis, lack of transfer of the methyl group of 5-methylfolate to homocysteine by methionine synthase causes an irreversible accumulation of the 5-methyl form of tetrahydrofolate, leading to a lack of other essential forms of folate coenzymes (Chanarin et al 1989). For example, megaloblastic anaemia can be due to reduced levels of folate compounds required for DNA synthesis. Also, further metabolism of formiminoglutamic acid whch is formed in the catabolism of histidine depends on the activity of two folate enzymes, glutamate formiminotransferase and formiminotetrahydrofolate cyclodeaminase. Thus functional deficiency of folate coenzymes could lead to the marked increase of urinary formiminoglutamic acid excretion seen in our patient. However, this was not described in other cblE patients and was found in only one cblG patient (Shin et al 1986). This compound was apparently not measured in other patients and it is unclear whether this is a consistent feature of this disorder.

Reduced formation of labelled serine from $\left[{ }^{14} \mathrm{C}\right]$ formate in cultured fibroblasts presumably reflects reduced activity of the 5,10-methylenetetrahydrofolate-dependent serine hydroxymethyltransferase (Strong and Schirch, 1989), possibly due to restricted availability of this folate coenzyme. Inhibition of serine hydroxymethyl transferase by 5methyltetrahydrofolate (Strong and Schirch 1989) seems unlikely to be the explanation of 
low serine formation since we found no lowering of serine formation in the presence of very high concentrations of this folate coenzyme in patient or control cells. Defective serine formation has also been observed in fibroblasts of patients with combined homocystinuria/ methylmalonic aciduria, in which there is low methionine synthase activity and defective methylcobalamin synthesis (cblC/D mutants) (Fowler et al 1997). Such a deficient activity is unlikely to influence in vivo levels of serine since this amino acid can be formed by additional reactions. In addition, the expected low levels of $S$-adenosylmethionine, which inhibits methylenetetrahydrofolate reductase, might lead to increased formation of 5methyltetrahydrofolate, thereby exacerbating the trapping of folates (Surtees et al 1991).

The clear biochemical and haematological improvement on high-dose folate treatment, although without clear clinical improvement, has not been reported in other patients with functional methionine synthase deficiency. Folate treatment alone has been reported in only 2 other patients. In one with the cblE defect (Schuh et al 1984), no improvement of the homocystinuria or mental state was found. In the other, with the cblG defect and in whom formiminoglutamic acid excretion was also increased (Shin et al 1986), no reference was made to the sulphur amino acid concentrations, although improved $\mathrm{Hb}$ and MCV but not clinical state were reported. In this latter patient, clinical improvement was reported after folinic acid treatment but no obvious decrease in formiminoglutamic acid excretion was observed. In 3 other patients (cblG) folate was used but combined with other treatment, so that its independent effect cannot be assessed.

In our patient there was a marked clinical improvement on vitamin $\mathrm{B}_{12}$ treatment (Mecbl in our case) in common with other cblE/G patients, although the MCV remained high. However, only on Mecbl combined with folate was there a sustained clinical, biochemical and haematological improvement. Other patients may also have benefited from a similar combined treatment (Rosenblatt et al 1987; Carmel et al 1988). A study in fibroblasts indicates that methylcobalamin does not directly increase methionine synthase activity (Chu et al 1993). Therefore, Mecbl is probably acting after conversion to hydroxocobalamin, as indicated by in vitro studies on the human enzyme (Kolhouse et al 1991), and longer-term use of the latter form of $\mathrm{B}_{12}$ may also have been effective in this child. The findings in this child emphasize the need to consider a wide range of therapeutic agents in similar patients.

In intact cultured fibroblasts, synthesis of methionine and serine showed no clear responses to supplementation of the growth medium with various forms of folate, singly or combined with methyl cobalamin. The only in vitro response was a slight increase of methionine and greater increase of serine with cobalamin at the very high concentration of $10 \mathrm{mg} / \mathrm{L}$. This is in contrast to the virtual normalization of methionine and serine formation, in response to hydroxocobalamin and methylcobalamin at lower levels of $1 \mathrm{mg} / \mathrm{L}$, in cblC/D cells (Fowler et al 1997). The differences between in vivo and in vitro responsiveness to cofactors in this patient may reflect the complexity of action of methionine synthase as well as the less physiological state of the cultured cell system.

Studies of methionine synthase from E. coli, pig liver (Frasca et al 1986; Chen et al 1994) and human placenta (Utley et al 1985) have indicated a complex mechanism of action of methionine synthase. In a proposed model (Banerjee and Matthews 1990) there is reduction of the cob(II)alamin form of the enzyme coupled with methylation utilizing $S$ adenosylmethionine as methyl group donor. The active methylated cob(I)alamin form of the 
enzyme donates its methyl group to homocysteine, forming methionine. The demethylated cob(I)alamin form is either remethylated by methyltetrahydrofolate or oxidized to the cob(II)alamin form, necessitating a continual reductive activity.

Therefore, different mutations may affect different steps in this reaction sequence, leading to much biochemical and clinical heterogeneity. Similarly, the response to folate treatment and increased forminimoglutamic acid excretion in our patient points to heterogeneity within the cblE mutant class.

\section{ACKNOWLEDGEMENTS}

Drs P. Fleury and R.S. Weening (Amsterdam) are acknowledged for their clinical support. We thank Mrs W.J.M. Berntsenn for her expert technical assistance. D.S.R. is a principal investigator in the Medical Research Council of Canada Genetics Group. B.F. is supported by grant 32-45988.95 from the Swiss National Science Foundation.

\section{REFERENCES}

Anderson BB, Peart MB. Fulford-Jones CE (1970) The measurement of serum pyridoxal by a microbiological assay using Lactobacillus casei. J Clin Pathol 23: 232-242.

Banerjee RV, Matthews RG (1990) Cobalamin-dependent methionine synthase. FASEB J 4: 1450-1459.

Baumgartner ER, Stokstad ELR, Wick H, Watson JE, Kusano G (1985) Comparison of folic acid coenzyme distribution patterns in patients with methylenetetrahydrofolate reductase and methionine synthetase deficiencies. Pediatr Res 19: 1288-1292.

Boss GR (1985) Cobalamin inactivation decreases purine and methionine synthesis in cultured lymphocytes. J Clin Invest 76: $213-218$.

Carmel R, Watkins D, Goodman SI, Rosenblatt DS (1988) Hereditary defect of cobalamin metabolism (cblG mutation) presenting as a neurologic disorder in adulthood. $N$ Engl J Med 318: $1738-1741$.

Chanarin I, Deacon R, Lumb M, Perry J (1989) Cobalamin-folate interrelations. Blood Rev 3: 211-215.

Chen Z, Crippen K, Gulati S, Banerjee R (1994) Purification and kinetic mechanism of mammalian methionine synthase from pig liver. J Biol Chem 269: 27193-27197.

Chu RC, Begley JA, Colligan PD, Hall CA (1993) The methylcobalamin metabolism of cultured human fibroblasts. Metabolism 42: 315-319.

Duran M, Ketting D, Wadman SK, Jakobs C, Schutgens R, Veder H (1978) Organic acid excretion in a patient with 3-hydroxy-3-methylglutaryl-CoA lyase deficiency: facts and artefact. Clin Chim Acta 90: $187-193$.

Fenton WA, Rosenberg LE (1995) Inherited disorders of cobalamin transport and metabolism. In: Scriver CR, Beaudet AL, Sly WS, Valle D eds. The Metabolic and Molecular Bases of Inherited Disease, 7th edn. New York: McGraw-Hill, 3129-3150.

Fowler B (1982) Transsulphuration and methylation of homocysteine in control and mutant human fibroblasts. Biochim Biophys Acta 721: 201-207.

Fowler B, Kraus J, Packman S, Rosenberg LE (1978) Homocystinuria: evidence for three distinct classes of cystathionine beta synthase mutants in cultured fibroblasts. J Clin Invest 61: 645-653.

Fowler B, Whitehouse C, Wenzel F, Wraith JE (1997) Methionine and serine formation in control and mutant human cultured fibroblasts: evidence for methyl trapping and characterization of remethylation defects. Pediatr Res 41: 145-151.

Frasca V, Riazzi BS, Matthews RG (1986) In vitro inactivation of methionine synthase by nitrous oxide. J Biol Chem 261: 15823-15826.

Gijzen AHJ, de Koch HW, Meulendijk PN, et al (1983) The need for a sufficient number of low level sera in comparisons of different serum $B_{12}$ assays. Clin Chim Acta 127: 185-195. 
Hall CA (1990) Function of vitamin $B_{12}$ in the central nervous system as revealed by congenital defects. Am J Hematol 34: 121-127.

Higginbottom MC, Sweetman L, Nyhan WL (1978) A syndrome of methylmalonic aciduria, homocystinuria, megaloblastic anemia and neurologic abnormalities in a vitamin $\mathrm{B}_{12}$ deficient breastfed infant of a strict vegetarian. N Engl J Med 299: 317-323.

Kolhouse JF, Utley C, Stabler SP, Allen RH (1991) Mechanisms of conversion of human apo- to holomethionine synthase by various forms of cobalamin. J Biol Chem 266: 23010-23015.

Lowry OH, Rosebrough NHJ, Farr AL, Randall RJ (1951) Protein measurement with the Folin phenol reagent. J Biol Chem 193: 265-275.

Mellman I, Willard HF, Rosenberg LE (1978) Cobalamin binding and cobalamin-dependent enzyme activity in normal and mutant human fibroblasts. J Clin Invest 62: 952-960.

Mukulu DR, Smith EF, Bertino JR (1973) Lack of dihydrofolate activity in brain tissues of mammalian species: possible implications. J Neurochem 21: 241-245.

Niederwieser A, Gilberti P, Matasovic A, Pluznik S, Steinmann B, Baerlocher K (1974) Folic acid non-dependent formiminoglutamic acidaemia in two siblings. Clin Chim Acta 54: 293-316.

Rosenblatt DS, Erbe DW (1977) Methylenetetrahydrofolate reductase in cultured human cells. 1. Growth and metabolic studies. Pediatr Res 11: 1137-1141.

Rosenblatt DS, Cooper BA, Pottier A, Lue-Shing H, Matiaszuk M, Grauer K (1984) Altered vitamin $\mathrm{B}_{12}$ metabolism in fibroblasts from a patient with megaloblastic anemia and homocystinuria due to a defect in methionine biosynthesis. J Clin Invest 74: 2149-2156.

Rosenblatt DS, Cooper BA, Schmutz SM, Zaleski WA, Casey RE (1985) Prenatal vitamin B $_{12}$ therapy of a fetus with methylcobalamin deficiency (cobalamin E disease). Lancet 1: 1127-1129.

Rosenblatt DS, Thomas IT, Watkins D, Cooper BA, Erbe RW (1987) Vitamin $B_{12}$ responsive homocystinuria and megaloblastic anaemia. Am J Med Genet 26: 377-383.

Schuh S, Rosenblatt DS, Cooper BA, et al (1984) Homocystinuria and megaloblastic anemia responsive to vitamin $\mathrm{B}_{12}$ therapy. $N$ Engl J Med 310: 686-690.

Shin YS, Reiter S, Zelger O, Brunstler I, Rucker AV (1986) Orotic aciduria, homocystinuria, formiminoglutamic aciduria and megaloblastosis associated with the formiminotransferase/ cyclodeaminase deficiency. In: Nyhan WL, Thompson F, Watts RWE, eds. Purine and Pyrimidine Metabolism in Man. Plenum Press, New York, 71-76.

Strong WB, Schirch V (1989) In vitro conversion of formate to serine: effect of tetrahydropteroylglutamates and serine hydroxymethyltransferase on the rate of 10-formyltetrahydrofolate synthetase. Biochemistry 28: 9430-9439.

Surtees R, Leonard J, Austin S (1991) Association of demyelination with deficiency of cerebrospinal fluid $S$-adenosylmethionine in inborn errors of methyl-transfer pathway. Lancet 338: 1550-1554.

Tabor H, Wijngarden L (1958) A method for the determination of formiminoglutamic acid in urine. $J$ Clin Invest 37: 824-827.

Tuchman M, Kelly P, Watkins D, Rosenblatt DS (1988) Vitamin B $_{12}$-responsive megaloblastic anaemia. homocystinuria and transient methylmalonic aciduria in cblE disease. J Pediatr 113: $1052-1056$.

Utley CS, Marcell PD, Allen RH, Antony AC, Kolhouse JF (1985) Isolation and characterization of methionine synthetase from human placenta. J Biol Chem 25: 13656-13665.

van Kapel J, Spijkers LJM, Lindemans J, Abels J (1983) Improved distribution analysis of cobalamins and cobalamin analogues in human plasma in which the use of thiol-blocking agents is a prerequisite. Clin Chim Acta 131: 211-224.

Voogd CE, Blok-Scholten MGA, Spalberg EC (1985) Stability of folic acid activity in serum. Med Lab Sci 42: 233-236.

Watkins D, Rosenblatt DS (1988) Genetic heterogeneity among patients with methylcobalamin deficiency. J Clin Invest 81: 1690-1694.

Watkins D, Rosenblatt DS (1989) Functional methionine synthase deficiency (cblE and cblG): clinical and biochemical heterogeneity. Am J Med Genet 34: 427-434.

Willard HF, Ambani LM, Hart AC, Mahoney MJ, Rosenberg LE (1976) Rapid prenatal and postnatal detection of inborn errors of propionate, methylmalonate and cobalamin metabolism: a sensitive assay using cultured cells. Hum Genet 34: 277-283. 